\title{
Keperawatan Wisatawan Pantai untuk Meningkatkan Keselamatan Wisatawan di Tempat Wisata
}

\section{Coastal Nursing Tourism to Improve Tourist Safety in Tourist Attraction}

\author{
Komang Ayu Henny Achjar \\ Jurusan Keperawatan, Politeknik Kesehatan Kemenkes Denpasar, Indonesia
}

\begin{tabular}{l} 
ARTICLE INFO \\
\hline Article history \\
Received date \\
25 August 2020 \\
Revised date \\
07 Oct 2020 \\
Accepted date \\
21 Oct 2020 \\
\hline
\end{tabular}

Keywords:

Coastal tourist nursing;

Safety;

Tourist.

\section{Kata kunci:}

Keperawatan wisatawan pantai;

Keselamatan;

Wisatawan

\begin{abstract}
ABSTRAK
Coastal tourist nursing takes an important role in managing health in coastal communities order. The improvement of accidents while traveling can occur due to natural phenomena and the negligence of tourists and lifeguards. Through the implementation of the coastal tourist nursing model, tourist safety can be improved by empowering lifeguards and community nurses as well as representing a multi-sectoral partnership between healthsector other sectors. This study used a quasi-experimental pre-post-test design with a control group and involved 118 lifeguards and 720 tourists. Sampling used the Cluster Sampling technique which was carried out on the coasts of Badung Regency. Data were analyzed with the chi-square test, t-test, and General Linear Model-Repeated Measure (GLM-RM). Measuring the safety of tourists using the benchmarks of knowledge, attitudes, and actions of tourists who studied with a questionnaire with the results of the validity test $r$-count $>0,361$ and reliability test with $r$-Alpha for knowledge 0,870 , attitude 0,888 , and behavior 0,915 . The increase was significant $(\mathrm{p}$-value $<0,05)$ in all aspects of tourists in the intervention group after 3 months of giving the intervention model. However, tourist safety tended to decrease after 6 months of intervention. Strengthening the implementation of models and communication between lifeguards and community nurses is needed to maintain community safety in specific coastal groups.
\end{abstract}

Keperawatan wisatawan pantai memegang peranan penting dalam pengendalian kesehatan di tatanan komunitas pantai. Kecelakaan saat berwisata dapat terjadi akibat fenomena alam, kelalaian wisatawan dan kondisi lifeguard. Melalui penerapan model keperawatan wisatawan pantai, keselamatan wisatawan dapat ditingkatkan dengan pemberdayaan lifeguard dan perawat komunitas sekaligus merepresentasikan kemitraan multi sektoral antara bidang kesehatan dengan bidang lainnya. Penelitian ini menggunakan metode quasy experiment pre-post-test design with control group dan melibatkan 118 lifeguard dan 720 wisatawan. Pengambilan sampel menggunakan teknik Cluster Sampling yang dilaksanakan di pantai Kabupaten Badung. Data dianalisis dengan uji chi square, uji t, General Linier Model-Repeated Measure (GLM-RM). Keselamatan wisatawan diukur dengan tolak ukur pengetahuan, sikap, dan tindakan wisatawan yang dikaji dengan kuisioner dengan hasil uji validitas $r$ hitung $>0,361$ dan uji reliabilitas dengan $\mathrm{r}$ Alpha pengetahuan 0,870, sikap 0,888, dan tindakan 0,915. Ditemukan peningkatan signifikan $(p$-value $<0,05)$ pada ketiga aspek tersebut pada responden kelompok intervensi setelah 3 bulan pemberian intervensi model. Namun keselamatan wisatawan cenderung menurun setelah 6 bulan pemberian intervensi. Penguatan penerapan model dan komunikasi antara lifeguard dan perawat komunitas sangat diperlukan untuk mempertahankan keselamatan masyarakat di kelompok khusus pantai.

Corresponding Author:

Komang Ayu Henny Achjar

Jurusan Keperawatan, Poltekkes Kemenkes Denpasar, Bali, Indonesia

Email: komangayuhenny@gmail.com

\section{PENDAHULUAN}

Keselamatan wisatawan pantai menjadi tolak ukur keberhasilan program pariwisata di Bali. Sebagai pusat wisata yang mengandalkan keanekaragaman wisata bahari, keberadaan penjaga pantai (lifeguard) merupakan strategi dalam menjamin keselamatan wisatawan pantai. Tingginya kunjungan wisata pantai di Bali menyebabkan potensi kecelakaan dalam 
beraktivitas semakin meningkat. Penelitian Siahaan (2013) mencatat telah terjadi 45 kasus kecelakan wisatawan di pantai Pondok Bali Pamanukan Subang pada tahun 2013. Paparan kasus kematian akibat tenggelam di Bali didominasi oleh kasus tenggelam di pantai sebesar 53,5\% (Usaputro \& Yulianti, 2013).

Kecelakaan pada aktivitas wisatawan di pantai disebabkan oleh faktor fisik dan biologis. Berdasarkan penelitian Muntasib, Ulfah, Samosir, \& Meilani (2018), potensi bahaya yang sering mengancam wisatawan di Pantai Pangandaran disebabkan oleh faktor fisik yaitu arus rip dan ombak tukik. Arus rip merupakan arus yang bergerak dari arah pantai menuju laut sedangkan ombak tukik merupakan ombak dengan kekuatan yang besar dan curam. Kedua kejadian tersebut sering menjadi penyebab terseretnya wisatawan ke arah pantai saat berenang. Fenomena yang sama juga terjadi di Pantai Kuta, Bali yang memiliki potensi karakteristik gelombang yang tinggi dan ekstrim (Hang \& Surabaya, 2016).

Penyelamatan wisatawan pantai merupakan upaya dalam mencegah dan meminimalisir kecelakaan melalui peningkatan pelayanan dan kemitraan. Upaya tersebut dapat dilakukan dengan mengevaluasi setiap risiko bahaya melalui manajemen bahaya yang meliputi penerimaan atas kejadian yang dapat ditoleransi, meminimalisir risiko, dan mengalihkan risiko. Pengelolaam bahaya dapat direalisasikan melalui pencegahan risiko secara primer maupun sekunder. Pencegahan primer meliputi pemberian edukasi kesehatan terkait potensi bahaya di pantai serta upaya pencegahannya sedangkan pencegahan sekunder dilakukan melalui deteksi dini terhadap bahaya, pertolongan pertama kecelakaan serta proses rujukan ke fasilitas kesehatan terdekat. Upaya pencegahan dapat dilakukan oleh tenaga profesional yang telah terintegrasi secara materi.

Fasilitas kesehatan tingkat pertama seperti Puskesmas bertanggung jawab atas kesehatan masyarakat dalam lingkup wilayah kerjanya. Puskesmas menjadi tempat bagi perawat komunitas untuk merealisasikan asuhan keperawatan dalam lingkup individu yang luas menurut Keputusan Menteri Kesehatan No. 1239 Tahun 2001. Selain melakukan asuhan keperawatan, perawat komunitas juga berperan sebagai educator, manajer kasus, penghubung, pembela, leader, care provider, peneliti, kolaborator, dan fasilitator di tatanan komunitas (Allender, Rector, \& Warner, 2014; Kulbok \& Ervin, 2012; Stanhope \& Lancaster, 2010; Lancaster \& Stanhope, 2014; Hitchcock,
Schubert, \& Thomas, 1999; Allender \& Spradley, 2012).

Keterlibatan elemen masyarakat yang beragam dalam proses keperawatan komunitas, membutuhkan kerja sama lintas sektoral yang meliputi sistem kelompok, pendidikan kesehatan, serta pemberdayaan dan kemitraan sesuai pengaplikasian dari teori model keperawatan community as partner (Lancaster \& Stanhope, 2014). Kemitraan dan pemberdayaan masyarakat dalam proses keperawatan berkaitan dengan keberhasilan intervensi keperawatan sekaligus membangun kemandirian masyarakat dalam mengelola kesehatannya sendiri (Melo \& Alves, 2019).

Teori community as partner dapat direlisasikan melalui konsep keperawatan wisatawan pantai yang melibatkan masyarakat dan stakeholder terkait untuk memajukan status kesehatan komunitas. Konsep keperawatan wisatawan di pantai melibatkan penanganan terintegrasi antara perawat, lifeguard, masyarakat sekitar, serta wisatawan. Lifeguard sebagai penggerak utama keselamatan wisatawan merupakan tenaga professional yang terlatih dalam penanganan pertama kasus kecelakaan di pantai. Kinerja lifeguard dipengaruhi oleh faktor lingkungan kerja dan kapasitas diri yang dimiliki. Minimnya fasilitas dan sarana prasarana pertolongan pertama di pos penjagaan pantai menjadi faktor penyebab keterlambatan proses penanganan pada kasus cidera sehingga menyebabkan kecacatan bahkan kematian pada korban. Sedangkan keberadaan lifeguard yang bertugas menjadi faktor internal dalam kelalaian kinerja di lapangan (Kusuma \& Suryawan, 2016).

Konsep keperawatan wisatawan pantai menjadi hal penting yang harus direalisasikan dalam mengupayakan keselamatan wisatawan. Kemitraan dengan perawat puskesmas yang mewilayahi pantai menjadi upaya penanganan dini kasus kecelakaan untuk pembinaan teknis medis. Kemitraan dengan Pemerintah Daerah Badung dalam hal ini adalah Dinas Kesehatan dan Dinas Pariwisata dalam pembinaan operasional non-teknis medis. Pemberdayaan lifeguard dan wisatawan merupakan pemanfaatan potensi yang ada di masyarakat. Melalui capacity building lifeguard berupa pelatihan untuk meningkatkan pengetahuan, sikap, dan tindakan sehingga diharapkan lifeguard dapat berkualitas dalam menjalankan tugasnya sebagai penjaga pantai, melakukan upaya promotif dalam penyampaian informasi terkait potensi dan rambu bahaya serta upaya pencegahan dan penanganan dini yang akan menjadi tolak ukur keberhasilan keselamatan wisatawan. Sehingga melalui 
keperawatan wisawatan berbasis pemberdayaan lifeguard dapat meningkatkan keselamatan wisawatan di tempat wisata.

\section{METODE}

Penelitian dilakukan dengan metode kuantitatif quasy experiment pre-post-test design dengan kelompok pembanding dan melibatkan lifeguard dan wisatawan sebagai responden. Teknik cluster sampling yang dilakukan pada wilayah Pantai Kuta Tengah menjadi kelompok perlakuan dan Pantai Kuta Selatan merupakan kelompok kontrol. Penelitian ini melibatkan 59 lifeguard dan 360 wisatawan pada kedua kelompok sehingga total responden berjumlah 118 lifeguard dan 720 wisatawan.

Intervensi diawali dengan pemberian modul asuhan keperawatan kelompok khusus dan buku kerja yang dibuat melalui proses konsultasi pakar kepada perawat dan lifeguard. Selanjutnya akan dilakukan pelatihan bagi perawat selama 4 hari dan lifeguard selama 3 hari sesuai dengan materi pada modul yaitu pengenalan program keperawatan wisatawan pantai, pencegahan cidera, dan SOP penanganan kecelakaan pantai dengan materi tambahan bagi perawat yaitu asuhan keperawatan komunitas pantai. Pemberian buku kerja bertujuan sebagai bukti dokumentasi pelaksanaan keperawatan wisatawan pantai sesuai program yang ditetapkan.

Tahap implementasi pada responden diawali dengan pre-test kepada wisatawan di kelompok intervensi dan kontrol (pre). Selanjutnya pelaksanaan intervensi berupa penerapan materi pelatihan oleh lifeguard kepada wisatawan pantai. Wisatawan diberikan edukasi kesehatan, pemahaman tentang tindakan serta penanganan yang tepat terkait kecelakaan di pantai. Perawat Puskesmas berperan dalam monitoring kegiatan yang dilakukan lifeguard seminggu sekali pada 3 bulan pertama dan sebulan sekali pada 3 bulan terakhir. Pengukuran keselamatan wisatawan pada kelompok perlakuan dilakukan kembali setelah 3 bulan intervensi (post-1) dan 6 bulan kemudian (post2). Sedangkan kelompok kontrol dilakukan setelah 3 bulan (post-1) dan 6 bulan (post-2) kelompok intervensi diberikan perlakuan.

Pengukuran keselamatan wisatawan menggunakan teknik pengumpulan data wawancara mendalam menggunakan Instrumen keselamatan modifikasi indikator keselamatan masyarakat mencakup pertanyaan terkait pengetahuan, sikap, dan tindakan (Stanhope \& Lancaster, 2016). Kuisioner terdiri dari 17 pertanyaan pengetahuan dengan kriteria penilaian $(0=$ salah; $1=$ benar $)$. Kuesioner sikap terdiri dari 16 pertanyaan $(0=$ Sangat tidak setuju; $1=$ tidak setuju; 2=setuju; 3=sangat setuju) Sedangkan kuesioner tindakan terdiri dari 16 pertanyaan dengan kriteria $0=$ tidak pernah; $1=$ kadang kadang; 2=sering; $3=$ selalu. Kuisioner telah melalui uji validitas dengan hasil $r$ hitung lebih besar dari $r$ tabel ( $r$ tabel 0,361) dan uji reliabilitas dengan $\mathrm{r}$ Alpha pengetahuan $=0,870$, sikap $=0,888$ dan tindakan $=0,915$. Data dianalisis menggunakan analisis univariat, bivariat, dan multivariat. Analisis bivariat menggunakan independent $t$-test, uji multivariat menggunakan General Linier Model-Repeated Measure (GLMRM) untuk menganalisis perbedaan variabel yang diukur berulang.

Peneliti telah memenuhi persyaratan uji lolos etik dari Komite Etik Fakultas Ilmu Keperawatan Universitas Indonesia dengan No. 0494/UN.2.F12.D/HKP.02.04/2016 denga ijin penelitian di wilayah Kabupaten Badung, Provinsi Bali dengan surat No. 070/726/Kesbang tanggal 13 Juli 2016. 


\section{HASIL}

Tabel 1. Karakteristik Wisatawan

\begin{tabular}{|c|c|c|c|c|c|c|c|}
\hline \multirow{2}{*}{$\begin{array}{c}\text { Variabel } \\
\text { Pendidikan }\end{array}$} & \multicolumn{3}{|c|}{ Intervensi } & \multicolumn{3}{|c|}{ Kontrol } & \multirow{2}{*}{ p-value } \\
\hline & <SMA & SMA & >SMA & <SMA & SMA & >SMA & \\
\hline Pre & 18 & 95 & 7 & 19 & 90 & 11 & 0,000 \\
\hline Post-1 & 10 & 62 & 48 & 15 & 73 & 32 & 0,011 \\
\hline Post-2 & 29 & 53 & 38 & 16 & 79 & 25 & 0,000 \\
\hline Jenis kelamin & Laki & & Perempuan & Laki & & Perempuan & \\
\hline Pre & 54 & & 66 & 53 & & 67 & 1,000 \\
\hline Post-1 & 70 & & 50 & 59 & & 61 & 0,104 \\
\hline Post-2 & 74 & & 46 & 81 & & 39 & 0,418 \\
\hline Frekuensi kunjungan & Mean & & Simpangan & Mean & & Simpangan & \\
\hline Pre & 4,48 & & 3,437 & 6,01 & & 3,568 & 0,001 \\
\hline Post-1 & 3,39 & & 2,349 & 6,12 & & 5,485 & 0,000 \\
\hline Post-2 & 6,68 & & 3,477 & 2,71 & & 1,126 & 0,000 \\
\hline
\end{tabular}

Hasil analisis menunjukkan karakteristik wisatawan pada kedua kelompok didominasi dengan wisatawan berpendidikan SMA. Kunjungan wisatawan berdasarkan jenis kelamin beragam antara sebelum intervensi (pre-test), 3 bulan setelah intervensi (post-1) dan 6 bulan setelah intervensi (post-2), sehingga tidak ada pengaruh bermakna dalam penyebarannya ( $p$ value $>0,05)$. Frekuensi kunjungan wisatawan juga tercatat beragam sehingga didapatkan perbedaan jumlah kunjungan antara wisatawan dengan intervensi dan wisatawan pembanding pada setiap pengukuran $(p$-value $<0,05)$.

Tabel 2. Keselamatan Wisatawan berdasarkan Pengetahuan, Sikap, dan Tindakan

\begin{tabular}{|c|c|c|c|c|c|c|c|}
\hline \multirow{2}{*}{$\begin{array}{l}\text { Keselamatan } \\
\text { Wisatawan } \\
\end{array}$} & \multicolumn{3}{|c|}{ Kelompok Intervensi } & \multicolumn{3}{|c|}{ Kelompok Kontrol } & \multirow{2}{*}{$\begin{array}{l}\text { Nilai } \\
p^{* *}\end{array}$} \\
\hline & Pengetahuan & Sikap & Tindakan & Pengetahuan & Sikap & Tindakan & \\
\hline \multicolumn{8}{|l|}{ Pre } \\
\hline- Mean & 86,52 & 69,45 & 63,49 & 85,93 & 69,48 & 60,48 & $0,77 p^{l}$ \\
\hline -Median & 88,24 & 68,75 & 64,58 & 88,24 & 68,75 & 62,50 & $0,97 p^{2}$ \\
\hline -Simpangan & 15,62 & 9,6 & 17,83 & 16,06 & 9,28 & 15,94 & $0,17 p^{3}$ \\
\hline -Min-Maks & $17,7-100$ & $39,6-87,7$ & $16,7-93,8$ & $17,7-100$ & $43,8-87,5$ & $16,7-85,4$ & \\
\hline -SK 95\% mean & 84-89 & 68-71 & $60-67$ & 83-89 & 68-71 & $58-63$ & \\
\hline \multicolumn{8}{|l|}{ Post-1 } \\
\hline- Mean & 97,99 & 90,47 & 82,52 & 88,78 & 67,01 & 59,83 & $0,000 p^{l}$ \\
\hline -Median & 100 & 91,67 & 63,33 & 94,12 & 66,67 & 60,42 & $0,000 p^{2}$ \\
\hline -Simpangan & 3,37 & 8,06 & 13,64 & 14,25 & 9,40 & 15,20 & $0,000 p^{3}$ \\
\hline -Min-Maks & $82,4-100$ & $68,8-100$ & $50-100$ & $47,1-100$ & $22,9-85,4$ & $25-100$ & \\
\hline -SK $95 \%$ mean & 97-99 & 89-92 & $60-67$ & 86-91 & $65-69$ & $57-63$ & \\
\hline \multirow[t]{3}{*}{ **Pre-Post 1} & \multicolumn{3}{|c|}{$0,000 \mathrm{p}^{1}$} & \multicolumn{3}{|c|}{$0,411 p^{1}$} & \\
\hline & \multicolumn{3}{|c|}{$0,000 \mathrm{p}^{2}$} & \multicolumn{3}{|c|}{$0,093 \mathrm{p}^{2}$} & \\
\hline & \multicolumn{3}{|c|}{$0,000 \mathrm{p}^{3}$} & \multicolumn{3}{|c|}{$1,000 \mathrm{p}^{3}$} & \\
\hline \multicolumn{8}{|l|}{ Post-2 } \\
\hline -Mean & 99,02 & 84,20 & 80,28 & 88,78 & 61,68 & 54,05 & $0,000 p^{l}$ \\
\hline -Median & 100 & 84,38 & 79,17 & 94,12 & 60,41 & 54,71 & $0,000 p^{2}$ \\
\hline -Simpangan & 2,57 & 8,06 & 9,41 & 13,92 & 7,66 & 12,15 & $0,000 p^{3}$ \\
\hline -Min-Maks & $88,2-100$ & $66,7-100$ & $52,08-100$ & $47,1-100$ & $41,7-85,4$ & $25-83,3$ & \\
\hline -SK 95\% mean & 99-100 & $60-63$ & $79-82$ & 86-91 & 83-86 & $52-56$ & \\
\hline \multirow[t]{3}{*}{$* *$ Pre-Post 1} & \multicolumn{3}{|c|}{$0,000 p^{I}$} & \multicolumn{3}{|c|}{$0,411 p^{I}$} & \\
\hline & \multicolumn{3}{|c|}{$0,000 p^{2}$} & \multicolumn{3}{|c|}{$0,000 p^{2}$} & \\
\hline & \multicolumn{3}{|c|}{$0,000 p^{3}$} & \multicolumn{3}{|c|}{$0,000 p^{3}$} & \\
\hline
\end{tabular}

Catatan : *Uji independent $\mathrm{t}\left(\right.$ antar kelompok); ${ }^{*} \mathrm{Uji}$ independent $\mathrm{t}($ pre-post $) ; p^{I}=$ pengetahuan; $p^{2}=$ sikap; $p^{3}=$ tindakan

Hasil analisis keselamatan wisatawan yang direpresentasikan melalui jawaban responden terkait perkembangan pengetahuan, sikap, dan tindakan diketahui mengalami perbedaan yang signifikan antara kedua kelompok. Nilai pada kelompok intervensi meningkat di setiap pengukuran keselamatan wisatawan dari sebelum perlakuan hingga pengukuran 6 bulan kemudian ( $p$-value $<0,05)$. 
Tabel 3. Keselamatan Wisatawan Sebelum dan Sesudah Intervensi Model

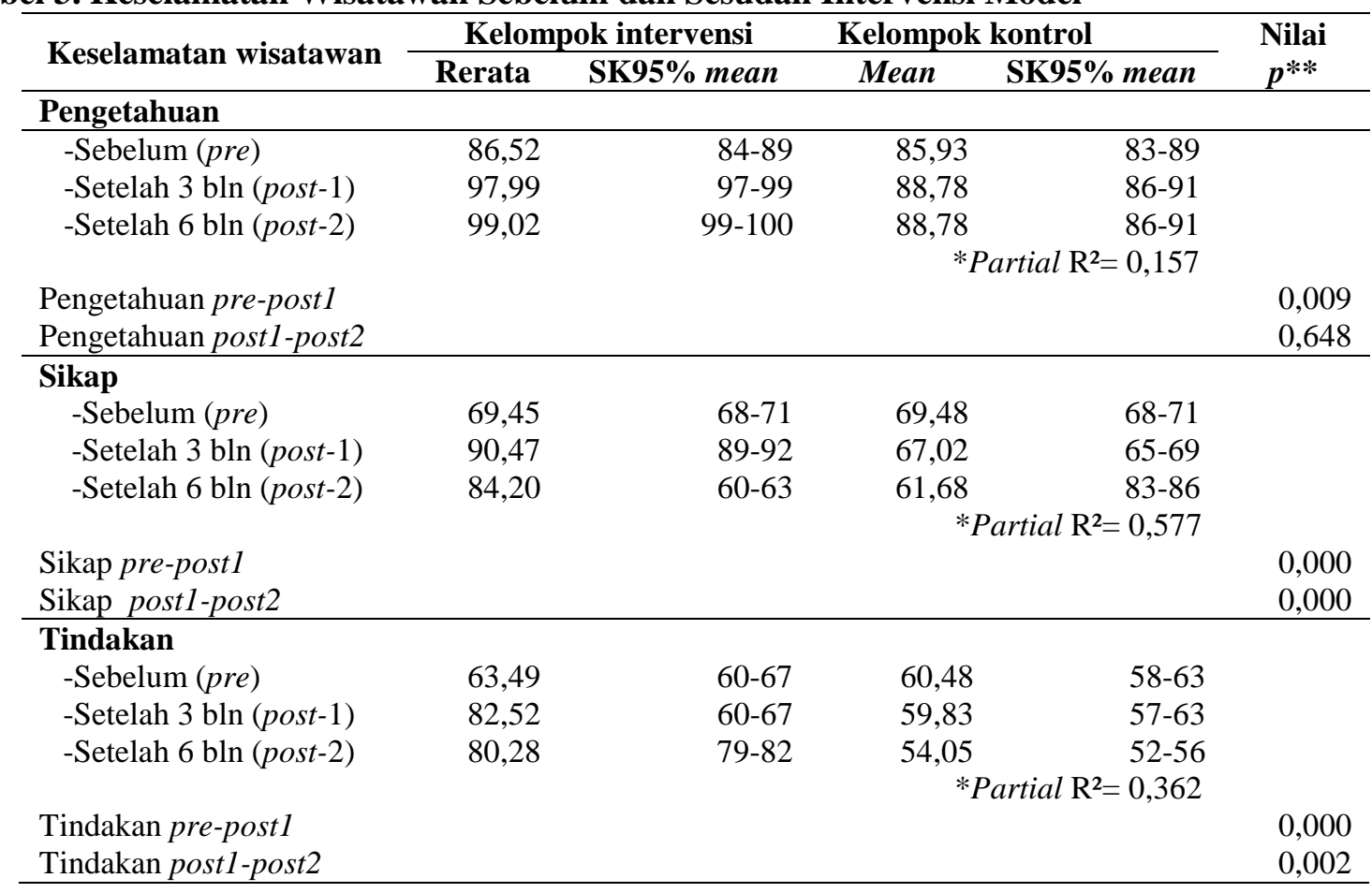

Uraian pada tabel 3 menjabarkan ada perbedaan bermakna perilaku dan tindakan atas pemahaman responden terkait keselamatan di pantai dalam jangka waktu pengukuran pre-post 1 dan post 1-post 2 ( $p$-value $<0.005)$. Sedangkan perbedaan nilai pengetahuan hanya terjadi pada pengukuran saat pre menuju post 1 saja.Waktu pengukuran memberikan dampak yang signifikan pada pemahaman responden dengan p-value 0,000 . Nilai yang signifikan membuktikan bahwa keselamatan wisatawan dipengaruhi oleh interaksi pada kelompok dan waktu evaluasi. Model keperawatan wisatawan pantai mempengaruhi $15,7 \%$ atas peningkatan pengetahuan, $57,7 \%$ sikap, dan $36,2 \%$ tindakan keselamatan wisatawan.

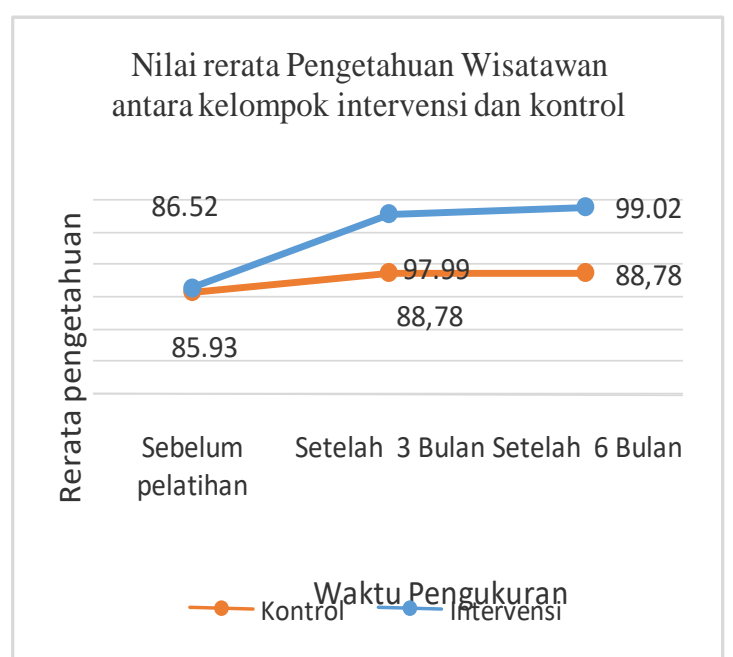

Gambar 1. Pengetahuan Keselamatan Wisatawan menurut Waktu Pengukuran

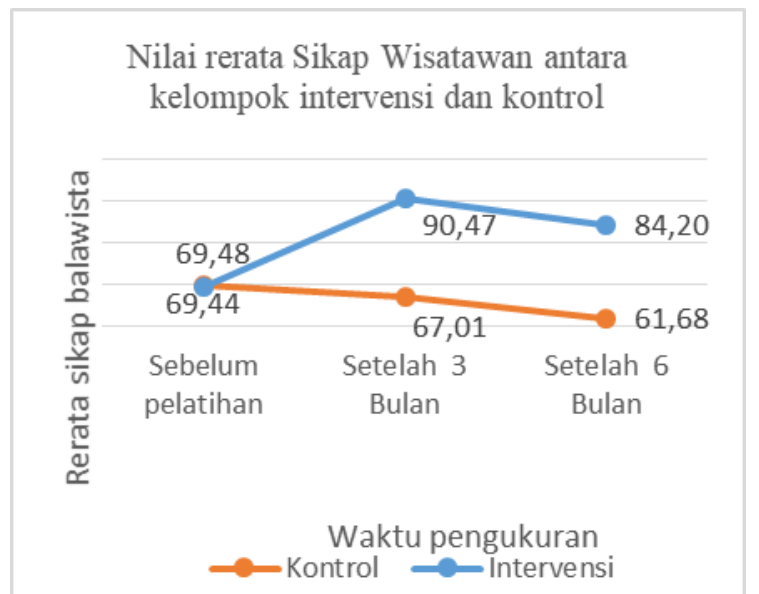

Gambar 2. Sikap Keselamatan Responden menurut Waktu Pengukuran

Nilai rerata Tindakan Wisatawan antara kelompok intervensi dan kontrol

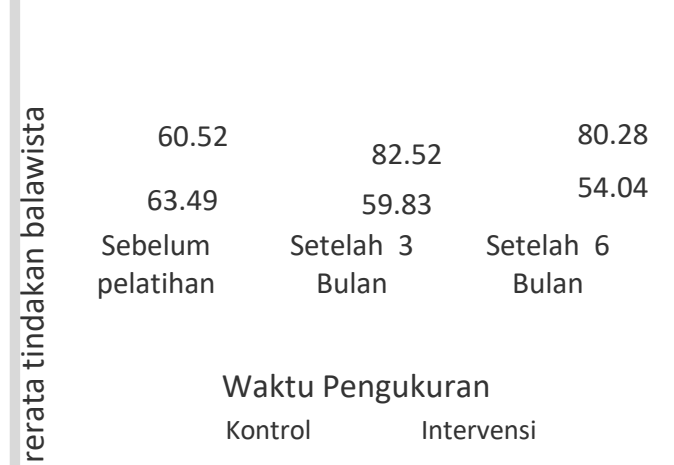

Gambar 3. Tindakan Keselamatan Responden menurut Waktu Pengukuran 
Tabel 4. Faktor Penentu Nilai Pengetahuan, Sikap, dan Tindakan Keselamatan Wisatawan

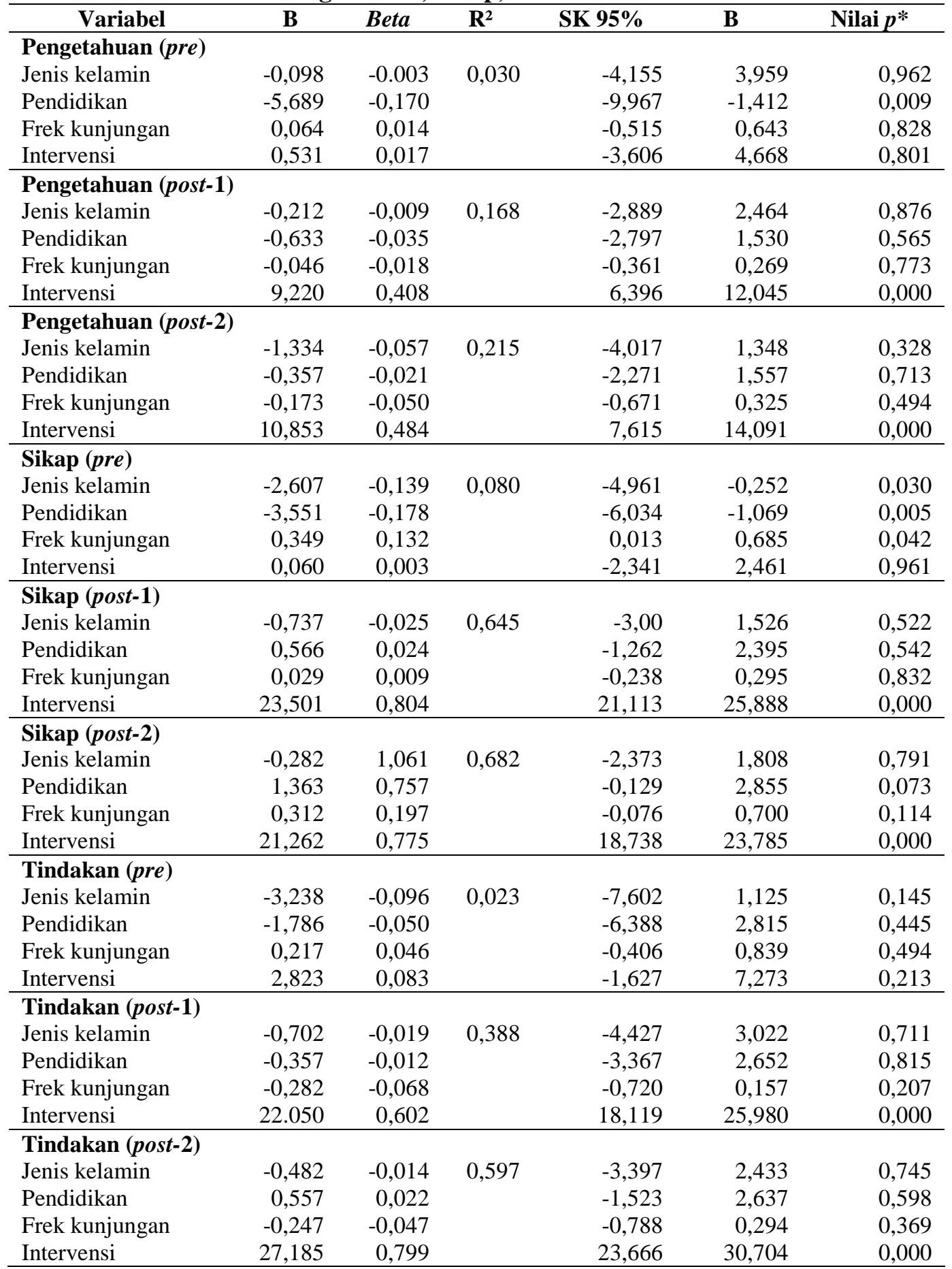

Hasil uji regresi linier ganda menunjukkan faktor penentu peningkatan nilai aspek keselamatan wisatawan di 3 tahap pengukuran dipengaruhi oleh pemberian intervensi model dengan nilai $p$-value $<0,05$.

\section{PEMBAHASAN}

Pengaruh Model Keperawatan Wisatawan Pantai terhadap Pengetahuan Keselamatan Wisatawan

Distribusi karakteristik wisatawan yang dikaji berdasarkan pendidikan, gender, dan frekuensi kunjungan dalam tabel 1 tampak tersebar merata pada kedua kelompok sehingga bias pada hasil penelitian dapat diminimalisir. Keselamatan wisatawan diukur berdasarkan pemahaman wisatawan terhadap pengetahuan, 
sikap, dan tidakan dalam mencegah dan menangani potensi bahaya saat beraktivitas di pantai. Setelah melalui analisis data, aspek pengetahuan responden pada kelompok yang diberikan perlakuan sebelum pemberian model keperawatan wisatawan pantai tercatat serupa dengan kelompok kontrol. Peningkatan terjadi setelah dilakukan pengukuran 3 bulan penerapan intervensi sebesar 11,47 sedangnya pada kelompok kontrol hanya meningkat sebesar 2,85. Peningkatan yang signifikan terhadap hasil pelatihan dalam 3 bulan juga terjadi dalam penelitian Boissy, et al., (2016) terkait pengaruh pelatihan komunikasi terhadap kepuasan pasien. Jangka waktu 3 bulan menjadi jangka waktu ideal bagi para responden untuk menerapkan materi yang diperoleh dalam pelatihan karena responden berada pada fase beradaptasi terhadap ilmu baru yang telah diterima. Proses edukasi dan sosialiasi manajemen bahaya di pantai kepada wisawatan melalui model keperawatan wisatawan pantai dilakukan secara tutor (teori) dan juga praktik. Lifeguard dapat berperan memberikan promotif dan preventif kepada wisatawan berupa pengarahan saat melakukan surfing, menunjukkan rambu-rambu bahaya yang ada di pantai yang harus dipatuhi, serta melakukan pengawasan terhadap tindakan yang berpotensi menimbulkan bahaya bagi wisatawan. Mekanisme kerja lifeguard tersebut sejalan dengan penelitian (Graham, et al., 2018) bahwa menggerakkan pengetahuan menjadi tindakan dapat mendukung keberhasilan suatu program yang telah ditetapkan.

Keberhasilan peningkatan pengetahuan wisatawan terkait keselamatan wisatawan pantai tidak terlepas dari pelatihan yang telah diberikan kepada lifeguard sebelum pelaksanaan intervensi model. Lestari, Warseno, Trisetyaningsih, Rukmi, \& Suci (2020) menyatakan bahwa keberhasilan peningkatan status kesehatan masyarakat berkaitan dengan pemberdayaan kader yang telah terlatih. Kader yang dalam penelitian ini merupakan lifeguard telah melalui proses pelatihan terkait penyesuaian teori dan praktik terbaru yang berkembang di dunia pendidikan dalam penanganan dan pencegahan kasus kecelakaan di pantai. Pada pelatihan lifeguard juga diberi edukasi terkait metode komunikasi yang baik kepada wisatawan sehingga proses edukasi kesehatan dapat berlangsung dan diterima dengan baik.

Rerata nilai pengetahuan keselamatan wisatawan pada kelompok intervensi setelah 6 bulan pelaksanaan intervensi meningkat 1,03 sedangkan pada kelompok kontrol tidak terjadi peningkatan. Intervensi model keperawatan wisatawan pantai mempengaruhi tingkat pengetahuan wisatawan terhadap keselamatan pantai, namun pengaruh tersebut tidak sebesar saat pengukuran setelah 3 bulan intervensi diberikan. Penerapan materi pelatihan yang tidak dilakukan secara dinamis dapat menurunkan kemampuan peserta pelatihan. Kelemahan dalam melatih pengetahuan pada orang dewasa yaitu peningkatan kognitif cendurung menurun jika setelah 3 bulan tidak diberikan intervensi kembali (Ballesteros, 2015). Sedikitnya kenaikan pada nilai pengetahuan wisatawan setelah 6 bulan pelaksanaan intervensi dapat diperkuat kembali dengan brosur keselamatan, komunikasi perawat secara individu ataupun kelompok, bahkan dapat dilakukan saat pelatihan surfing secara langsung maupun tidak langsung.

Peningkatan yang signifikan terjadi pada meningkatnya nilai pengetahuan pada kelompok intervensi setelah penerapan model keeperawatan wisatawan dibuktikan dengan $p$-value $<0,05$. Melalui pelatihan kepada subjek/responden secara tidak langsung, dapat menekan potensi kecelakaan di lingkungan sekitar (Nissa \& Amalia, 2018). Dengan berlangsungnya proses wisata yang aman, akan mendorong minat wisatawan internasional maupun domestik untuk kembali berkunjung bahkan mendorong wisatawan lain untuk berkunjung ke Bali khususnya pantai di Badung. Sehingga dapat menunjang sektor ekonomi dan pariwisata di Bali.

\section{Pengaruh Intervensi Keperawatan terhadap Sikap Keselamatan Wisatawan}

Rerata pengukuran sikap keselamatan wisatawan pada kelompok yang diberikan perlakuan mengalami peningkatan setelah 3 bulan penerapan model sebesar 21,02, sedangkan pada kelompok pembanding mengalami penurunan sebesar 2,47. Meningkatnya pengetahuan terkait keselamatan pantai pada wisatawan dapat memberikan gambaran terkait hal yang baik dan tidak baik dilakukan. Keselamatan diri wisatawan selain tanggung jawab lifeguard, juga merupakan tanggung jawab wisatawan itu sendiri. Maka dari itu dengan mengetahui hal yang harus dilakukan untuk menjaga keselamatan dapat mempengaruhi sikap wisawatan dalam berperilaku. Sejalan dengan penelitian Rusmilawati, Adhani, \& Adenan (2017), peningkatan sikap dalam mengobati penyakit terjadi setelah pemberian pelatihan oleh petugas kesehatan.

Setelah 6 bulan perlakuan, rerata sikap keselamatan wisatawan kelompok intervensi 
menurun sebesar 6,27. Penurunan tersebut cenderung terjadi kerena menetap/statisnya kinerja lifeguard setelah 6 bulan intervensi. Namun dengan pendampingan yang dilakukan oleh perawat puskesmas, penurunan nilai sikap tidak mencapai 50\% dari nilai keseluruhan. Perawat komunitas sebagai tenaga kesehatan professional dalam penelitian ini merupakan supervisior terhadap pemberdayaan lifeguard di tatanan kesehatan komunitas pantai. Tenaga kerja profesional cenderung memberikan edukasi dan pelayanan yang positif berkaitan kualitas dan tingkat edukasi yang dimilikinya (Abell, BraggUnderwood, Alexander, Abell, \& Burd, 2015). Sehingga komunikasi dan kemitraan penting untuk tetap dijaga antara petugas kesehatan dengan pelaku wisata.

\section{Pengaruh Model Keperawatan Wisatawan Pantai terhadap Tindakan Keselamatan Responden}

Nilai rerata tindakan keselamatan wisatawan pada kelompok intervensi setelah 3 bulan penerapan model keperawatan wisatawan pantai mengalami kenaikan 19,03 sedangkan pada kelompok kontrol menurun sebesar 0,65. Peningkatan tindakan oleh wisatawan dipengaruhi oleh pengetahuan yang dimilikinya. Terdapat kecenderungan pada diri wisatawan untuk menghindari sumber bahaya ataupun melakukan pencegahan selama berkegiatan wisata di pantai. Didukung dengan penelitian Nurjanatun (2012) bahwa kesadaran wisatawan untuk memanfaatkan klinik wisata semakin meningkat setelah penerapan intervensi sesuai dengan budaya wisata.

Nilai rerata wisatawan dalam bertindak pada kelompok intervensi setelah 3 bulan tahap post-1, mengalami penurunan sebesar 2,24. Penurunan tersebut seiring dengan penurunan rerata nilai sikap dan pengetahuan wisatawan. Penerapan pelatihan tidak sekedar untuk memperoleh pengetahuan dan keterampilan saja, namun pemahaman untuk mengembangkan sikap yang diperlukan merupakan hal penting yang dimiliki oleh peserta pelatihan. Menurut Sharmal \& Nuttal (2016), program pendidikan guru memiliki tanggung jawab terhadap pengembangan sikap yang diperlukan. Semakin berkualitas kompetensi seorang guru, maka akan meningkatkan proses penerimaan dan pemahaman materi bagi peserta didik. Peran lifeguard pada keselamatan wisawatan merupakan hal penting untuk menjaga keberlangsungan program pariwisata di Bali. Meskipun pelatihan dan metode edukasi yang diberikan sudah tergolong baik, namun jika tidak didukung oleh kompetensi lifeguard dan perawat komunitas maka tidak akan menjamin keberhasilan penyelamatan kesehatan pada komunitas pantai.

Penerapan model keperawatan wisatawan pantai tidak hanya untuk memajukan kualitas pariwisata di Bali, namun juga melindungi wisatawan yang diatur dalam Undang-undang No. 8 tahun 1999 tentang perlindungan konsumen pariwisata, Undang-undang No. 10 tahun 2009 pasal 20 tentang kepariwisataan menyebutkan bahwa wisatawan memiliki hak mendasar yaitu memperoleh informasi yang akurat mengenai pelayanan kepariwisataan sesuai dengan standar keselamatan, pelayanan kesehatan saat melakukan kegiatan pariwasata yang berisiko tinggi.

Model keperawatan wisatawan pantai merupakan program kerja lintas sektoral yang melibatkan kinerja dan kreatifitas lifeguard, dan perawat komunitas serta partisipasi aktif dari stakeholder terkait. Kerja sama multi-sektoral merupakan tindakan berkelanjutkan sekaligus kunci utama peningkatan kesehatan dan kesejahteraan masykarakat (World Health Organization, 2018). Sehingga model keperawatan wisatawan pantai tepat diupayakan dalam memajukan keselamatan wisatawan sekaligus kesejahteraan masyarakat khususnya di wilayah pantai.

\section{SIMPULAN}

Peningkatan keselamatan wisatawan dalam aspek pengetahuan, sikap, dan tindakan pada 3 bulan setelah intervensi, mengindikasikan bahwa program keperawatan wisawatan memberikan pengaruh positif bagi perkembangan sistem pariwisata di Bali. Peningkatan tersebut belum mampu dipertahankan pada pengukuran 6 bulan berikutnya, sehingga penerapan model keperawatan wisatawan pantai membutuhkan peranan aktif dari lifeguard serta perawat komunitas untuk selalu memonitor keselamatan pantai. Sehingga kesehatan komunitas dapat menunjang keberlangsungan dalam segi pariwisata dan ekonomi di Bali. 


\section{DAFTAR PUSTAKA}

Abell, C., Bragg-Underwood, T., Alexander, L., Abell, C. E., \& Burd, V. (2015). Nurses' Knowledge and Attitudes toward Implementation of Electronic Medical Records. International Journal of Faith Community Nursing, 1(3), 74.

Allender, J, Rector, \& Warner. (2014). Community \& Public Health Care. Lippincott Williams \& Wilkins.

Allender, J. ., \& Spradley, B. (2012). Community health and nursing, concept and practice. California: Lippincott Williams \& Wilkins.

Ballesteros, S. (2015). A randomized controlled trial of brain training with non-action video games in older adults: results of the 3-month. Clinical Trial, 7(April), 1-12. https://doi.org/10.3389/fnagi.2015.00045

Boissy, A., Windover, A. K., Bokar, D., Karafa, M., Neuendorf, K., Frankel, R. M., ... Rothberg, M. B. (2016). Communication Skills Training for Physicians Improves Patient Satisfaction. Journal of General Internal Medicine, 31(7), 755-761. https://doi.org/10.1007/s11606-016-3597-2

Graham, I. D., Kothari, A., McCutcheon, C., Alvarez, G., Banner, D., Botti, M., ... Tetroe, J. (2018). Moving knowledge into action for more effective practice, programmes and policy: Protocol for a research programme on integrated knowledge translation. Implementation Science, 13(1), 1-15. https://doi.org/10.1186/s13012-017-0700-y

Nurcahyo, M.A., Kisnarti EA. (2016). Analisis Karakteristik Tinggi Gelombang Ekstrem dan Nilai Transfomrasi Gelombang Pantai Kuta Bali. Seminar Nasional Kelautan keXVI. Surabaya: Fakultas Teknik dan Ilmu Kelautan Universitas Hang Tuah.

Hitchcock, J., Schubert, P., \& Thomas, S. (1999). Community Health Nursing Caring in Action. New York: Delmar Publisher.

Kulbok, P., \& Ervin, N. (2012). Nursing Science and Public Health, Contributing to The Discipline of Nursing. Nursing Science.

Kementerian Kesehatan RI. (2001). Keputusan Menteri Kesehatan Nomor 1239 Tentang Registrasi dan Praktik Perawat. Jakarta.

Kusuma, S. W., \& Suryawan, I. B. (2016). Penerapan Keselamatan Dan Kesehatan Kerja Balawista Di Pantai Kuta. Jurnal Destinasi Pariwisata, 4(1), 31. https://doi.org/10.24843/jdepar.2016.v04.i 01.p06

Lancaster, J., \& Stanhope, M. (2014). Public
Health Nursing Population Centered Health Care in the Community (8th ed.). St. Louise: Mosby.

Lestari, R., Warseno, A., Trisetyaningsih, Y., Rukmi, D. K., \& Suci, A. (2020). Pemberdayaan Kader Kesehatan Dalam Mencegah Penyakit Tidak Menular Melalui Posbindu Ptm. Adimas: Jurnal Pengabdian Kepada Masyarakat, 4(1), 48. https://doi.org/10.24269/adi.v4i1.2439

Melo, P., \& Alves, O. (2019). Community Empowerment and Community Partnerships in Nursing Decision-Making. Healthcare, $7(2), \quad 76$. https://doi.org/10.3390/healthcare7020076

Muntasib, E. H., Ulfah, M. M., Samosir, A., \& Meilani, R. (2018). Potensi Bahaya Bagi Keselamatan Pengunjung Di Kawasan Wisata Pantai Pangandaran Kabupaten Pangandaran Jawa Barat. Jurnal Pengelolaan Sumberdaya Alam Dan Lingkungan (Journal of Natural Resources and Environmental Management), 8(1), 1525. https://doi.org/10.29244/jpsl.8.1.15-25

Nissa, U. N., \& Amalia, S. (2018). Pengaruh Keselamatan dan Kesehatan Kerja Terhadap Kinerja Karyawan. Jurnal Riset Bisnis Dan Investasi, 3(3), 69. https://doi.org/10.35697/jrbi.v3i3.946

Nurjanatun, D. (2012). Hubungan Tingkat Pengetahuan dan Sikap Wisatawan terhadap Pemanfaatan Klinik Wisata. [Skripsi]. Semarang: Fakultas Kedokteran, Universitas Diponegoro.

Rusmilawati, R., Adhani, R., \& Adenan, A. (2017). Pengaruh Pelatihan Terhadap Pengetahuan Sikap Dan Ketidakrasionalan Pengobatan Diare Non Spesifik Sesuai Mtbs Pada Balita. Jurnal Berkala Kesehatan, $1(2), \quad 52$. https://doi.org/10.20527/jbk.v1i2.3143

Sharmal, U., \& Nuttal, A. (2016). The impact of training on pre-service teacher attitudes, concerns, and efficacy towards inclusion. Asia-Pacific Journal of Teacher Education. Asia-Pacific Journal of Teacher Education, 44(2).

http://www.tandfonline.com/loi/capj20.

Siahaan, G. M. K. (2013). Pengembangan Fasilitas keamanan bagi keselamatan berwisata di pantai Pondok Bali Pamanukan Subang. [Skripsi]. Bandung: Fakultas Pendidikan Ilmu Pengetahuan Sosial, Universitas Pendidikan Indonesia. Stanhope, \& Lancaster. (2010). Foundations of 
Nursing In The Community, communityoriented practice (2nd ed.). St. Louise: Mosby Elsevier.

Stanhope, M., \& Lancaster, J. (2016). Public Health Nursing Population Centered Health Care in The Community (8th ed.). St. Louise: Mosby.

Undang-undang Republik Indonesia. UndangUndang No. 8 tahun 1999 tentang perlindungan konsumen. Jakarta.

Undang-undang Republik Indonesia. UndangUndang No. 10 tahun 2009 pasal 20 tentang kepariwisataan. Jakarta.

Usaputro, R., \& Yulianti, K. (2013).
Karakteristik serta faktor resiko kematian akibat tenggelam berdasarkan data Bagian Ilmu Kedokteran Forensik Rumah Sakit Umum Pusat Sanglah 20102012. Bagian Ilmu Kedokteran Forensik Fakultas Kedokteran Udayana.

World Health Organization (WHO). (2018). Multisectoral and intersectoral action for improved health and well-being for all: mapping of the WHO European Region. Governance for a sustainable future: improving health and well-being for all. In World Health Organization Regional Office for Europe. Denmark. 